\title{
Somali - Kenya Deniz Sınırı İhtilafı
}

\section{Somalia - Kenya Maritime Delimitation Dispute}

\author{
M. Cem OĞULTÜRK*
}

$\ddot{O}_{\boldsymbol{z}}$

Bu çalışmanın amacı Kenya ve Somali arasındaki deniz sinırı ihtilafina iki ülke arasında yaşanan kara sinırı sorunlarının etkisini incelemektir. Hint Okyanusu boyunca aynı kayl şeridini paylaşan ve Afrika Kitasinın kuzey doğusunda bulunan iki ülke arasındaki mevcut deniz sinır ihtilafi, iki devletin kara sinırından deniz sınırının uygun yönüne ilişkin farkl yorumlanmasindan kaynaklanmaktadır. İki ülkenin deniz sinırı ihtilafinı çözme konusundaki başarısız müzakere girişimlerinin ardından, Somali Uluslararası Adalet Divanı'na 28 Ağustos 2014 tarihinde Kenya aleyhinde dava açma başvurusunda bulunmuş ve mahkemenin nihai kararı beklenmektedir. Uluslararası Adalet Divanı'nın açıklayacağı karar benzer sorunlar yaşayan ülkeler için de önem arz etmektedir. Çalışmada Kenya içerisinde yaşayan Somalili nüfusun, Kenya'nın soruna yaklaşımında önemli bir faktör olduğu savunulmaktadır. Çalışmada nitel araștırma yöntemlerinden literatür taramasl, içerik ve söylem analizi kullanılmuştır. Son yillarda Somali-Türkiye ilişkilerinin geldiği nokta göz önüne alındığında çalışmanın Somali'nin yaşadı̆̆ deniz sinırı ihtilafinın incelenmesi Türk literatürüne katkı yapması açısından çalışmanın önemli olduğu değerlendirilmiştir.

Anahtar Kelimeler: Sinır Anlaşmazlı̆̆ı, Deniz Güvenliği, Münhasır Ekonomik Bölge, Somali, Kenya.

\footnotetext{
* Dr., Millî Savunma Üniversitesi Misafir Öğretim Görevlisi, ORCID No: 0000-00032619-9559, e-posta: cogulturk@ gmail.com.

Geliş Tarihi / Submitted: 04.04.2020 Kabul Tarihi / Accepted: 20.06.2020
}

\section{9}

Güvenlik Stratejileri

Cilt: 16

Say1: 35 


\section{Cem OĞULTÜRK}

\section{0}

Güvenlik Stratejileri

Cilt: 16

Sayı: 35

\section{Abstract}

The aim of this study was to examine the impact of land border issues between Kenya and Somalia over the disputes of maritime delimitation problems. The current maritime delimitation dispute between the two countries sharing the same coastline along the Indian Ocean and located in the north-east of the African Continent is due to the divergent interpretation of the two States from the land border as to the appropriate direction of the maritime border. Following the failed negotiations between the two countries on resolving the maritime border dispute, on 28 August 2014, Somalia filed a complaint before the International Court of Justice before Kenya, and the final judgment of the court is awaited. The decision to be announced by the International Court of Justice is also important for countries with similar problems. The study argues that the Somali population living in Kenya is an important factor in Kenya's approach to the problem. In the study, literature review, content and discourse analysis, which are among the qualitative research methods, were used. In recent years, when considering the point where SomaliaTurkey relations, it is evaluated that the study is important in terms of contributing to the Turkish literature by examining maritime delimitation dispute experienced by Somalia.

Keywords: Border Dispute, Maritime Security, Exclusive Economic Zone, Somalia, Kenya.

\section{Giriş}

Afrika ülkeleri, sınırlarındaki etnik şiddet, terörizm, ayrılıkçı hareketler, kaçakçılık, uyuşturucu ticareti gibi birçok problemle mücadele etmektedir. Kıta genelinde pek çok ülke bu sorunlarla karş1 karşıya kalmaktadır. Özellikle sömürge döneminde başat güçlerin boyunduruğu altında olması ve sonrasında Soğuk Savaş döneminde iki süper gücün bu ülkelerde yürüttüğü vekâlet savaşları nedeniyle bölge oldukça yıpratmıştır. Bugün Afrika'da görülen istikrarsızlık, iç çatışma ve karışıklıkların başlıca sebeplerinden birisi, sömürge yönetimlerinin geride kasten bıraktıkları suni sınırlardır.

Batılı sömürgeci devletlerin 19'uncu yüzyılda başlayan saldırılarına maruz kalan Somali, İngiliz, Fransız ve İtalyanlar tarafından işgal edilmiş 
ve İkinci Dünya Savaşı sonrasına kadar sömürgeci devletlerin Somali toprakları üzerindeki paylaşımları devam etmiştir. Sömürge dönemi sonrası İngiltere, Somali'de yönetimi altındaki topraklardan önemli bir bölümünü kendisi ile ortak hareket etmelerinin mükâfatı olarak Somalilerin çoğunlukta oldukları Ogaden bölgesini Etiyopya'ya ve Kuzey Doğu Bölgesi olarak adlandırılan bölgeyi ise Kenya'ya bırakmıştır. Somalililer ise bu durumu kabul etmemiş ve gerekirse savaşarak da olsa bu bölgeleri ele geçirmek için mücadele yürütmüştür. ${ }^{1}$

Somali'nin geçmişten günümüze batı komşusu Kenya ile olan ilişkilerinin Etiyopya ile kıyaslandığında daha 1 lımlı olduğu görülmektedir. Farklı pek çok etnik gruptan meydana gelen Kenya halkı da Somalililere benzer şekilde uzun süre sömürge olarak yaşamış ve 1960'ların başlarında bağımsızlığını kazanmış, sınırları diğer Afrika devletlerine benzer şekilde cetvelle çizilmiştir. ${ }^{2}$ Sömürge dönemi sonrası Kenya, zaman zaman ülke içi sorunlar yaşasa da Somali ile kıyaslandığında çok daha istikrarlı bir yapıya sahip olmuştur.

Çalışmada Kenya ile Somali arasında yaşanan kara sınır sorunlarının yanında deniz sınırlarında oluşan problemlerinde yaklaşımının benzer olduğu ve bunun en büyük sebebinin Kenya içerisindeki Somali kökenli vatandaş ve mültecilerin, Kenya'nın güvenlik algısını olumsuz etkilemesidir. Güvenlik perspektifinde konuya bakıldığında Somali'nin Kuzey Doğu Bölgesi üzerine yayılmacı politikasının Kenya-Somali ilişkilerine olumsuz etkisinin gözden kaçırılmaması da gerekmektedir. ${ }^{3}$

Somali ile Kenya arasında yaşanan deniz sınırı ihtilafinda, Kenya'nın ülke içinde yaşayan Somalilileri bir güvenlik sorunu olarak

\footnotetext{
${ }^{1}$ Charles L. Geshekter, “Anti-Colonialism and Class Formation: The Eastern Horn of Africa before 1950." The International Journal of African Historical Studies, 1985, Vol. 18, no. 1 s. 1-32.

2 Afyare Abdi Elmi, "Somali Kimlik İslami Hareketler ve Barış", Açılımkitap, 2012, s. 169.

${ }^{3}$ Paul Vandenberg, "Ethnic-Sectoral Cleavages and Economic Development: Reflections on the Second Kenya Debate", The Journal of Modern African Studies, 2003, Vol. 41, No. 3, Sep., ss. 437-455.
}

\section{1}

Güvenlik Stratejileri

Cilt: 16

Say1: 35 


\section{Cem OĞULTÜRK}

522

Güvenlik Stratejileri

Cilt: 16

Sayı: 35

tanımlaması çalışmanın hipotezi olarak belirlenmiştir. Uluslararası Adalet Divanı'nın da gündeminde olan Somali-Kenya deniz sınırı ihtilafının nasıl çözümleneceği sorusu, hem Afrika'da hem de dünyanın diğer bölgelerinde yaşanan karasuları, kıta sahanlı̆̆ı ve münhasır ekonomik bölge tartışmalarına örnek teşkil etmesi çalışmanın önemini oluşturmaktadır.

$\mathrm{Bu}$ çalışmada, geçmişten günümüze Somali ve Kenya ilişkileri, Kenya'da yaşayan Somalili nüfus, kavramsal olarak karasuları, kıta sahanlığı ve münhasır ekonomik bölgesi kavramları kapsamında incelenecek ve hâlen çözülememiş Kenya ile Somali arasındaki deniz sınırı ihtilafı irdelenecektir. Çalışmada nitel araştırma yöntemlerinden literatür taraması, içerik ve söylem analizi kullanılmıştır. Münhasır ekonomik bölge ve deniz yetki alanları konusunun Türkiye'nin bir diğer Afrika ülkesi Libya ile imzaladığı anlaşma ile kazandığı popülarite ve önem nedeniyle, Somali-Kenya deniz ihtilafinda çıkacak sonuç Türkiye açısından önem taşımaktadır. Ayrıca son yıllarda Somali-Türkiye ilişkilerinin geldiği nokta göz önüne alındığında çalışma Somali'nin yaşadığı uluslararası bir sorunun incelenmesi Türk literatürüne katkı yapması açısından çalışmanın önemli olduğu değerlendirilmiştir.

\section{Kuramsal Çerçeve}

Çalışmada, "Kenya, Somali'nin yaşadığ 1 sorunlarda nasıl bir rol üstlenmiştir?", "Karasuları, Kıta Sahanlığı ve Münhasır Ekonomik Bölge kavramları çerçevesinde Kenya-Somali arasında yaşanan deniz sınırı sorununa çözüm bulunabilir mi?" ve "Kenya'da yaşayan Somalililerin Kenya ile ilişkilere etkisi nelerdir?" sorularına "İnşacı Kuram" çerçevesinde cevap aranacaktır.

Soğuk Savaş öncesi statik olan uluslararası sistem Soğuk Savaşın sona ermesiyle birlikte birçok farklı aktörün katıldığı dinamik bir hal almıştır. Bu kapsamda özellikle devletleri uluslararası arenada artık tekdüze tehditler haricinde asimetrik olarak karşılaşabileceği bazı unsurlar ile karşı karşıya kalmış ve izledikleri politikalara birçok değişken ve parametreleri dâhil etmek zorunda bırakılmışlardır. İnşacı kuram değişen sistemle ilgili yeni çözümlemelerde bulunmaya çalışmıştır. İnşacı yaklaşım savunucuları küreselleşme temelli oluşan krizler, 
ikilemler, değişim ve dönüşümlerin çözümlenmesinde salt güç ve piyasanın olmadığını bu sebeple fikirler, normlar, kültürler ve kimliklerin oluşturduğu sosyolojik yapının ele alınması gerekliliğinin zorunlu olduğunu ifade etmişlerdir. Devletlerin yekpare değil toplumla birlikte incelenmesinin önemli olduğunu vurgulamışlardır. Kuramın öncülerinden Alexander Wendt'e göre kimlik bir ülkenin diğerlerini dost ya da hasım olarak sınıflandırması noktasında temel değişkendir. ${ }^{4}$

Somali-Kenya ilişkilerinde ise Kenya'da yaşayan Somalili nüfusun bölgede yaşanan göç nedeniyle gittikçe artması, Somalili entelektüel nüfusun Kenya'nın yönetimini etkileyecek konumda bulunması ve bölge halkının Kenya Meclisinde temsilcilere sahip olması nedeniyle, Kenya'nın Somali politikasının Etiyopya'dan farklı olarak daha 1lımlı kaldığı değerlendirilmektedir. Kenya'nın Somali ile olan kara sınır sorunlarının yanında deniz sınırlarında oluşan ihtilafta da benzer yaklaşımının olduğu ve bunun en büyük sebebinin Kenya içerisindeki Somalili nüfusun, Kenya açısından yumuşak karın oluşturması söylenebilir. Güvenlik perspektifinde konuya bakıldığında inşacı kuramın savunduğu insanların benzer kimlikler arasında kendini güvende hissetmeleri ve kimliklerinin tanınmasının güvenlik kapsamında çok önemli olduğu ${ }^{5}$ düşüncesi, Kuzeydoğu Bölgesi'nde yaşayan Somalili nüfusun durumunun Kenya-Somali ilişkilerinde gözden kaçırılmaması gereken bir gerçek olarak karşımıza çıkarmaktadır.

\section{Somali-Kenya İlişskilerinin Kısa Tarihi}

Kenya toprakları içerisinde yer alan "Kuzey Doğu Bölgesi (North Eastern Province)"nin Somali ve Kenya arasında en önemli sorun olmasının başlica nedeni sömürge dönemi sonrası bölgede etkisini devam ettirmek isteyen İngiltere'nin 1926 y1lında "Kuzey Sınır Bölgesi (Northern Frontier District - NFD)"ni kapalı bölge ilan ederek

\footnotetext{
${ }^{4}$ Alexander Wendt, "Constructuring International Politics", International Security, 1995, Cilt 20, No 1, s. 71.

${ }^{5}$ Emre Çıtak ve Osman Şen, Uluslararası İlişkilerde Güvenlik Teorik Değerlendirmeler, Uluslararası İlişkiler Kütüphanesi, İstanbul, 2014, s. 116.
}

\section{3}

Güvenlik Stratejileri

Cilt: 16

Say1: 35 


\section{Cem OĞULTÜRK}

524

Güvenlik Stratejileri

Cilt: 16

Sayı: 35

Somali'nin güneyinden koparmasıdır. Dolayısıyla her ikisi de İngiltere'nin sömürgesi olan Kenya ve Somali arasındaki en önemli sorunu yine İngiltere yaratmıştır. 1. Dünya Savaşı sonrası İngiltere'nin sömürge yönetimi altında bulunan Jubaland'ın kuzeyi İtalya'ya mükâfat olarak bırakılmış, güney kısmı ise İngiltere'de kalmıștır. Somali'nin bağımsızlığını ilan etmesinden dört gün önce Somali'de düzenlediği resmî olmayan bir plebisitle ve altı Somali bölgesinden beşinin Somali Cumhuriyeti'ne katılmak istediği, büyük protesto gösterilerine rağmen "Kuzey Sınır Bölgesi"nin ise sömürge yönetiminin altında yaşamak istediği şeklinde sonuçlandırmış ve bölgeyi daha sonra Kenya'ya bırakarak bölgeden çekilmiştir. Kenya Kuzeydoğu Bölgesi olarak adlandırılan bu bölge bir başka deyişle Güney Somali Jubaland Bölge'sinden koparılan bölgedir. ${ }^{6}$

Bugün Kenya sınırları içerisinde 400.000'i mülteci yaklaşık 2,8 milyon Somalili çoğunlukla Kuzeydoğu Bölgesi'nde (Harita 1) yaşamını sürdürmektedir. Bölgedeki Somalililer bağımsızlıklarını kazanmak için 1960'larda halk hareketlerine başlamıştır. Etiyopya'nın Ogaden bölgesinde de benzer durumun yaşanması sebebiyle, Kenya ve Etiyopya Somali'nin "Büyük Somali" emellerini gerçekleştirmek istediğini iddia ederek Ortak Savunma Paktı imzalamışlar ${ }^{7}$ ve Afrika Birliği'nde Somali'ye karşı birlikte hareket etmişlerdir. Somali, Etiyopya ile olduğu gibi Kenya ile geniş çapta bir çatışmaya girmemiş, ancak Kenya 1964 ve 1977 Somali ile Etiyopya arasındaki savaşlarda Etiyopya'yı desteklemiştir. ${ }^{8}$

\footnotetext{
${ }^{6}$ History of NFD Kenya in Perspective, KenSom Kenya Somali Consortium, 12 December 2017, http://kenyasomali.blogspot.com/ (Erişim Tarihi: 22.04.2020)

${ }^{7}$ Stephen Musau, "Clans' and Clannism's Control Over Weak Political Institutions", The ITPCM, 2013 Vol. IX, no. 34 International Commentary, ss. 13-18.

${ }^{8}$ John Hathaway Spencer, "Ethiopia at Bay, A Personel Account of the Haile Sellassie Years”, Reference Publications, 1984, ss. 348-356.
} 


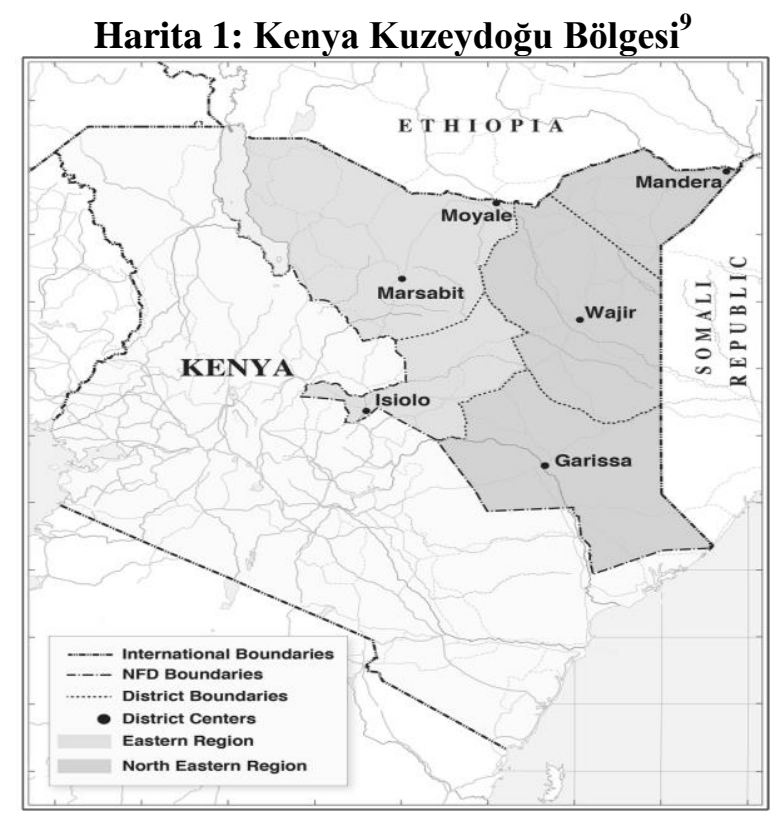

\section{5}

Güvenlik Stratejileri

Cilt: 16

Say1: 35

Ogaden Savaşı gibi büyük çaplı olmasa da, 1963-1967 yıllarında Kenya ile Somali arasında Kuzey Sınır Bölgesi'nde yaşayan ayrılıkçı Somalililerin öncülüğünde Shifta adı verilen çatışmalar gerçekleşmiştir. ${ }^{10}$ Tanzanya'da Zambia Başkanı Kaunda'nın 1967 yılında öncülük ettiği beşinci Afrika Birliği toplantısında sorun büyük oranda çözüme kavuşturulmuştur. ${ }^{11}$

\footnotetext{
9 Dominic Burbidge, “The Kenyan State's Fear of Somali Identity”, Accord, 2015. pp. 20-26. https://www.accord.org.za/conflict-trends/the-kenyan-states-fear-of-somaliidentity/ (Erişim Tarihi: 23.04.2020)

${ }^{10}$ https://www.kenyatalk.com/index.php?threads/today-in-history-shifta-war-longread.25037/ (Erişim Tarihi: 23.04.2020)

11 Arusha Agreement on Ending of Kenyan-Somali Border Hostilities.SomaliEthiopian Agreement. Keesing's Record of World Events (formerly Keesing's Contemporary Archives),Volume13, November, 1967 Kenya, Somalia, Ethiopia,
} 


\section{Cem OĞULTÜRK}

526

Güvenlik Stratejileri

Cilt: 16

Sayı: 35

Kenya'da yaşayan Somali toplumu ayrılıkçı tutuma sahip olsa da temsiliyet açısından durumları Etiyopya'nın Ogaden bölgesinde yaşayan Somalililerin durumundan oldukça farklıdır. Kenya'da bulunan Somalililer Kuzey Eyaleti İlerici Halklar Partisi (Northern Province Progressive Peoples Party-NPPPP) ile mecliste temsil hakkına ve ülke siyasetinde önemli bir etkiye sahiplerdir. Buna rağmen, ayrılıkçı Somalililerin şiddet eylemlerine giriştikleri görülmekte, Kenya merkezî hükümeti ise bu eylemlere oldukça kanlı bir şekilde cevap vermektedir. ${ }^{12}$

Sınır komşuları olan Kenya, Etiyopya ve Somali'nin bağımsızlıklarından itibaren aralarında sorunlar baş göstermiştir. Michael E. Brown'ın belirttiği üzere sınır ülkeler kendi menfaatleri sebebiyle çevresindeki ülkelerdeki çatışmalara müdahale edebilirler. ${ }^{13}$ Etiyopya Somali'nin sorunlarına muhaliflere verdiği destekle veya devlete karşı gruplar oluşturarak müdahil olmuştur. Kenya ise Etiyopya ile karşılaştırıldığında çok aktif olmamış, fakat kendi menfaatlerini korumak adına Somali'nin yayılmacı politikası ve bölgedeki Somalilileri birleştirmeye çalıştığı düşüncesini bir tehdit olarak değerlendirip zaman zaman Etiyopya ile birlikte hareket etmiştir. ${ }^{14}$

1991'de Siad Barre yönetiminin yıkılmasıyla birlikte Kenya'nın Somali politikası Etiyopya'nın tutumuna benzemeye başlamıştır. Bu zamana kadar Etiyopya ile aynı sorunu yaşamasına rağmen farklı bir strateji izleyen Kenya, Somali'de rejimin çöküşüyle sınırlarına gelen binlerce Somalilinin ilticasına izin vermiş ve sonucunda birçok güvenlik sorunlarıyla karşılaşmışırı. Bu tarihten sonra Kenya Somali'ye karşı daha aktif bir politika izlemesine sebep olmuştur.

Kenyan, Somali, Ethiopian, Page 22386.

12 From 'Shifta' War to Al Shabaab: Why Kenya is her own worst enemy, http://owaahh.com/shifta-war-to-al-shabaab/ (Erişim Tarihi: 23.04.2020)

${ }^{13}$ Michael E. Brown, "Internal Conflict: Causes and Implications", The International Dimension of Internal Conflicts", Michael E. Brown (Ed.), MIT Press, Cambridge, 1996, s. 33.

${ }^{14}$ Catherina Hoskyns, "Case Studies in African Diplomacy”, Dar Es Salaam,Nairobi and Addis Ababa, Oxford University Press, ss. vii-91. 
Kenya, 2007 yılına kadar askerî anlamda Somali’ye herhangi bir müdahalede bulunmamış, 2007 yılı itibariyle Etiyopya ve ABD ile birlikte İslam Mahkemeleri Birliğine karşı cephe almıştır. ABD desteğinde Etiyopya işgaline sınırlarını kapatarak Kenya'ya kaçmak isteyen militanları tutuklamıştır. 2007 yılında teşkil edilen "The African Union Mission in Somalia" (AMISOM)'a 2011 yılında 3500-4000 kişilik kuvvetiyle katılan Kenya, Eş-Şebab terör örgütüne karşı mücadelede önemli bir aktör olarak yer almaktadır. Kenya, Eş-Şebab'ın terör saldırılarının önemli hedeflerinden birisi olmuş ve 180 'den fazla asker hayatını kaybetmiş, turistlere yönelik kaçırma ve bombalı saldırı yaşanmıştır. $^{15}$ Kenya'dan zaman zaman askerlerini Somali'den çekeceğine dair açıklamalar gelse de Etiyopya'ya karşı bölgesel dengeler açısından bu kararı verebilmesi kolay değildir. Kenya, Somalili gruplara iç savaşın devamı için silah desteğinde bulunmasa da, Somali'deki birçok savaş ağası, siyasi gruplar ve kabile liderleri düzenli şekilde siyasi ve ticari nedenlerle Kenya ile ilişkilerine devam ettirmektedir.

Kenya'nın Somali'de politikasını değiştirmek zorunda kalmasının esas nedeni, Kenya Başbakanı Daniel Arap Moi'nin 2002 yılında ABD Ulusal Savunma Üniversitesi'nde yaptığı konuşmada açıkça belirttiği üzere "Büyük Somali" fikrinden korkulmasıdır. ${ }^{16}$ Ayrıca, 11 Eylül saldırıları sonrası radikal selefi terör örgütlere karşı küresel mücadele önem kazanmış, Eş-Şebab terör örgütünün Somali içerisinde elde ettiği toprak kazanımlarının ülke dışına yayılma tehlikesi, Kenya'nın Somali asıllı vatandaşlarına ve mültecilere bakışına şüphe katmıştır.

Kenya'da yaşayan Somalili nüfusun ülkede yaşanan iç savaş nedeniyle göçün gittikçe artması, Somalili entelektüel nüfusun Kenya'nın yönetimini etkileyecek konumda bulunması ve bölge halkının mecliste temsilcilere sahip olması nedeniyle Kenya'nın Somali politikasının Etiyopya'dan farklı olarak daha 1lımlıdır. Bununla birlikte, pek çok

\footnotetext{
${ }^{15}$ Sedat Aybar, "Kenya'da Terör Kimin İşine Yarar”, Cumhuriyet Gazetesi, 7 Ekim 2013, https://www.cumhuriyetarsivi.com/monitor/index.xhtml?cid=2 (Erişim Tarihi: 17.08.2020) 16 "Moi Speaks at the American Defence University", http://qaranka.com/right/ scan051a.pdf (Erişim Tarihi: 23.04.2020)
}

\section{7}

Güvenlik Stratejileri

Cilt: 16

Say1: 35 


\section{Cem OĞULTÜRK}

528

Güvenlik Stratejileri

Cilt: 16

Sayı: 35

Somalili iş adamı Nairobi'ye yerleşmiş ve Kenya ekonomisine büyük katkı sağlamışlardır. Somali'de bulunan birçok sivil toplum örgütü ve uluslararası kuruluşlar da Nairobi'ye taşınmıştır. Hatta bu konuyla ilgili Afyare Abdi Elmi alan araştırması için gittiği Nairobi'de görüştüğü birçok Somalili aydın, siyaset adamı, bürokrat ve yabancı diplomatların olması sebebiyle Somali'nin başkenti izlenimi verdiğini ifade etmiştir. ${ }^{17}$ $\mathrm{Bu}$ grupların yanı sıra iç savaşın yarattığı pek çok savaş ağası (warlord) kendilerine Nairobi'de rahat bir ortam bulmuşlardır. ${ }^{18}$

Kenya'nın kıyı bölgelerinde yaşayan Müslüman nüfus için ise güvenlik ve adalete ilişkin sorunlar ile genç işsizliği siyasal gerilimi artırmaktadır. Kıyı bölgelerde yaşayan Müslümanlar arasında yeşeren selefi terörizm tehdidi karşısında Kenya makamlarının sosyal ve ekonomik tedbirler yerine sertlikle karş1lık vermesi, Somali sınırından kaynaklı tehdit algısını da yükseltmektedir. ${ }^{19}$ Bunun sonucunda, eğer Kenya Somali'ye karşı daha aktif bir politika yürütmezse, istikrarlı bir sınır komşusu olması halinde Somali, Kenya için büyük bir tehdit unsuru olacağı düşüncesi kuvvet kazanmıştır.

Kültür ve din bağı olmasına rağmen ülkelerin politikaları ve güvenliği bağlamında izleyeceği çizginin daha çok sınır komşularına bağlı olduğunu görmekteyiz. Wallensteen ve Sollenberg'in belirttiği üzere sınır komşusu ülkeler iç savaşların sona erdirilmesi noktasında oldukça kritik bir role sahiptir. ${ }^{20}$ Kenya Somali'de yaşanan iç savaş ve terör sorununun çözülmesi için 17 yılda düzenlenen 17 toplantının üçüne ev sahipliği yapmıştır. Kenya doğu sınırında güçlü bir Somali devleti bulunmasını çıkarlarına aykırı bulmakta, ancak Somali'de bulunan terör örgütü EşŞebab'ın Kenya için de tehdit oluşturması örgüte destek verilmesinin

\footnotetext{
${ }^{17}$ Afyare Abdi Elmi, a.g.e., s. 170.

${ }^{18}$ Francis Openda, Cyrus Ombati, "Kenya: Warlords Who Call Nairobi Home”, AllAfrica All the Time, 16 October 2004, http://allafrica.com/stories/200410180169.html (Erişim Tarihi: 23.04.2020)

${ }^{19}$ Dominic Burbidge, a.g.e., s. 24.

${ }^{20}$ Peter Wallensteen \& Margereta Sollenberg, “Armed Conflict, 1989-2000”, Journal of Peace Research 38, Issue 5, 2001, s. 44.
} 
önüne geçmektedir. Somali bayrağında bulunan yıldızın uçlarının gösterdiği yerler olan Etiyopya-Ogaden ile Kenya-Kuzey Doğu Bölgesi Somali'nin yayılmacı politikasının simgesi olarak durmaktadır. Ancak, Kenya'nın Etiyopya'ya göre duruma yaklaşımda daha 1lımlı bir strateji izlediği ve Somali'nin iç sorunlarına çözüm bulunmasında daha girişken ve aktif bir politika izlemeye başladığı söylenebilir. ${ }^{21}$

Afrika Boynuzu'nda Etiyopya, Kenya ve Somali arasında iş birliğini geliştirici adımlar atılabilmesi yolunda Etiyopya'nın Mavi Nil Nehri üzerinde inşa ettiği Rönesans Barajı'nın üreteceği elektrik başta olmak üzere yaratacağı katma değerler ile büyük önem taşımakta. Kenya, Rwanda, Tanzania ve Uganda gibi Doğu Afrika ülkeleri Etiyopya'ya barajı inşa etme hakkı konusunda desteklemekteler. Juba ve Shabelle nehirleri havzalarına sahip Somali'nin barajdan gelecek sudan faydalanabilmesi Etiyopya ile ilişkilerine önemli etki oluşturabilecektir. Zira yıllardır devam eden kuraklık ve kitlık sorunlarının çözülmesi bölge ülkeleri arasında yaşanan göç olaylarının da önüne geçmesi muhtemeldir. ${ }^{22}$ Etiyopya'nın son yıllarda uluslararası sorunlarını çözme yolunda attığı adımlarla birlikte değerlendirildiğinde barajın faaliyete geçmesi ile birlikte Afrika Boynuzu'nda yeni bir dönem başlayabilir.

\section{Somali'nin Karasuları, Kıta Sahanlığı ve Münhasır Ekonomik Bölge Yaklaşımı}

Afrika ülkelerinin kara sınırları olduğu kadar deniz sınırlarında da çözümlenemeyen problemler mevcuttur. Özellikle teknolojinin gelişmesiyle birlikte tüm dünyada olduğu gibi bölgede keşfedilen zengin hidrokarbon rezervleri sonrası ülkeler karasuları, kıta sahanlığı ve münhasır ekonomik bölgeleri üzerindeki haklarını uluslararası

\footnotetext{
21 Afyare Abdi Elmi, s. 31.

22 Ashok Swain, "Grand Ethiopian Renaissance Dam: Catalyst for basin-wide water cooperation?", The Africa Report, 4 Ağustos 2020. https:/www.theafricareport.com/ 35797/grand-ethiopian-renaissance-dam-catalyst-for-basin-wide-water-cooperation/ (Erişim Tarihi: 17.08.2020)
}

\section{9}

Güvenlik Stratejileri

Cilt: 16

Say1: 35 


\section{Cem OĞULTÜRK}

530

Güvenlik Stratejileri

Cilt: 16

Sayı: 35

alanda aramaya başlamışlardır. Deniz sınırı sorunu sadece Afrika'da değil dünyanın dört bir yanında birçok ülkenin arasında mevcuttur. Özellikle küçük adaların sahip olduğu karasuları, kıta sahanlığı ve münhasır ekonomik bölgesi ve bu adaların sahibi sorunsalları birçok ülkeyi karşı karşıya getirmektedir. Buna yönelik olarak çoğu ülke hakkını aramak üzere çözemediği sınır problemlerini Uluslararası Adalet Divanı'na taşımaktadırlar.

Her bölgenin farklı tarihî bağları, doğal kaynakları ve coğrafi konumu ülkeler arasında hakkaniyetin sağlanmasını oldukça zorlaştırmaktır. Bu sebeple Uluslararası Adalet Divanı da ülkeleri daha çok kanunda yazan şekliyle olması gerektiğiyle değil öncelikle ülkelerin kendi arasında her ikisinin de lehine olacak şekilde anlaşmaya varmasını istemektedir. Önceden sadece balıkçılıkla ilgili olan sorunlar artık uluslararası petrol şirketlerinin bölge ülkeleri ile yaptıkları uzun dönemli anlaşmalar sonrası doğal kaynak keşifleri ile birlikte daha ciddi bir hal almıştır. Ayrıca birçok Afrika ülkesindeki istikrarsız yönetimlerin yerini artık güvenilir hükümetlerin almasıyla birçok yabancı yatırımcı için bölgenin değeri daha da artmıştır. Kenya'yı yukarıda belirtildiği üzere birçok şirket için yatırım noktası olduğunu görmekteyiz. Somali'nin de gerek kara sınırları gerekse deniz sınırları içinde sahip olduğu potansiyel zengin petrol rezervleri gelecekte ülkeyi coğrafi konumuyla birleşince çok önemli bir noktaya taşıyacağı aşikârdır. Hatta Kenya ile olan sınır anlaşmazlığı olan bölgedeki şirketlere Somali ile yeniden bir anlaşma yapabileceklerinin sinyalini vermiştir.

Somali hükümetleri ve uluslararası toplum 1999'dan bu yana, açık denizlerde korsanlıkla ilgili meseleler, Münhasır Ekonomik Bölge ilanı ve karasularında yasadışı balıkçılıkla mücadele gibi birçok hukuki ve güvenlik sorunlarıyla karşı karşıya kaldı.

Somali karasuları, kıta sahanlığı ve münhasır ekonomik bölgesine geçmeden önce kavramsal olarak karışıklığa sebep olan karasuları, kıta sahanlığı ve münhasır ekonomik bölgenin tam olarak ne anlama geldiği üzerinde durmak gerekir.

Karasularının genel olarak tanımı ve kapsamına bakacak olursak; "kıyı devletinin kara ülkesini çevreleyen uluslararası hukuka uygun 
olarak belirli bir genişliğe kadar uzanan kıyı devlete ait deniz alanı."23 şeklinde ifade edilebilir.

Birleşmiş Milletler Deniz Hukuku Sözleşmesi (BMDHS) 2. maddesine göre "Bir ülkenin egemenliği iç suları ve takımada olması halinde ona ait sularının ilerisinde kıyısı ile bitişik bölge sınırı arasında kalan bölümü o ülkenin karasularıdır". Aynı sözleşmenin 3. maddesinde ise "Her devletin kara sularının genişliğini tespit etme hakkına sahip olduğu belirtilirken, bu alanın 12 deniz milini aşmayan genişlikte olması" gerektiği öngörülmüştür. ${ }^{24}$

BMDHS'nde kara sularının hukuki statüsü hakkında ise "kıyı devleti, bu sularda ve üzerindeki hava sahasında geniş yetkilerle donatmıştır. Kıyı devletinin kara sularında egemenliği kara suların deniz yatağını ve toprak altını ve aynı zamanda üzerindeki hava sahasını da kapsar. Kıyı devleti kara sularına sahip olmakla bu yetkisini ilana tabi olmaksızın kullanabildiği” belirtilmiştir. ${ }^{25}$

Ülkeler için egemenlik kavramının kapsamını sınırlayan bazı hususlar vardır; açık denizlerin serbestliği ilkesi de bunlardan biridir. $\mathrm{Bu}$ kapsamda yabanc1 devletlerin seyrüsefer deniz seferlerinin kesintisiz bir şekilde devam etmesi bir haktır. "Zararsız Geçiş Hakkı" denen bu hak; kıyısı bulunsun ya da bulunmasın, bütün devletlere ait gemiler, sahil devletin barışına, düzenine ve özellikle güvenliğine etki etmeden geçebilmesini sağlamaktadır. Diğer bir sınır ise sahildar devletin diğer devletlere ait gemilerdeki yargılama hakkıdır. Bu sınırlamaların dışında kıyı ülkesinin egemenliği tamdır. ${ }^{26}$

\footnotetext{
${ }^{23}$ Hüseyin Pazarcı, Uluslararası Hukuk Dersleri, 2. Kitap, Ankara, 3. Bası, 1993, s. 293.

${ }^{24}$ Birleşmiş Milletler Deniz Hukuku Sözleşmesi, Birleşmiş Milletler Enformasyon Merkezi UNIC-Ankara, 1982. bkz. http://did.cevreorman.gov.tr/did/Files/UNCLOS.pdf , (Erişim Tarihi: 28 Mart 2011). Enver Bozkurt "Uluslararası Hukuk Bakımından Münhasır Ekonomik Bölge Kavramının Ortaya Çıkışı", Uluslararası Hukuk ve Politika, 2006, Cilt 2, No: 5 ss. 50-74.

${ }^{25}$ Nuray Karapınar, "Birleşmiş Milletler Deniz Hukuku Sözleşmesi ve Deniz Alanlarına İlişkin Bazı Kavramlar”, Doğal Kay. ve Eko. Bült., 2015, Sayı 20: 13-21.

26 Mesut Hakkı CAŞIN, "Askeri ve Stratejik Açıdan Montreux'nün Dünü ve
}

\section{1}

Güvenlik Stratejileri

Cilt: 16

Say1: 35 


\section{Cem OĞULTÜRK}

532

Güvenlik Stratejileri

Cilt: 16

Sayı: 35

Karasularından sonra gelen ve kenar devletin sinırlı da olsa bazı noktalarda yetkilerini kullandığı açık deniz bölgesini kapsayan alana bitişik bölge denir. Cenevre'de 1958 yılında düzenlenen konferansta bitişik bölge ile ilgili bazı değişiklikler yapılmış ve 1982 tarihli BMDHS 33. Maddesi ile farklı olarak karasularının bittiği noktadan 12 mil ötesi olarak belirlenmiştir. ${ }^{27}$

Bitişik bölgenin amacını inceleyecek olursak; karasularının üç mil olduğu dönemde devletlerinin bu kadar küçük alanda bazı haklarının tehdit edilmesi durumu ortaya çıkmasından kaynaklandığını söylemek yanlış olmayacaktır. Bitişik bölge ile hem kıyı devletinin hareket alanı genişletilmiş hem de denizlerin serbestîyeti ilkesinin devamlılığ ve istikrarı sağlanmıştır. ${ }^{28}$

Kıta sahanlığı kavramı coğrafi ve hukuki açıdan farklı anlamlara gelmektedir. Fakat çalışmamız daha çok hukuk alanını ilgilendirmesi sebebiyle bu yönlü ele alınacaktır. ${ }^{29}$ Kıta sahanlığ 1 kavramı BMDHS'de şu şekilde belirtilmiştir:

"Bir kıyı devletinin Kita Sahanlığı, kara ülkesinin doğal uzantısı boyunca Karasularının ötesinde kıta kenarının dış sınırına kadar uzanan veya kıta kenarının dış sınırının (200 mile kadar uzanmadığı) yerlerde, Kara sularının ölçülmeye başlandığ 1 esas hatlardan itibaren 200 mile kadar uzanan su altı alanlarının deniz yatağı ve toprak altını kapsar,"30

Geleceği”, Milletlerarası Hukuk ve Milletlerarası Özel Hukuk Bülteni”, Milletlerarası Hukuk Ve Milletlerarası Münasebetler Araştırma Ve Uygulama Merkezi, Kültür Sanat Basımevi, Y1l 37, Sayı 1, 2017, s. 82.

${ }^{27}$ G. Ç. Ceyhun, E. Z. Oral, "Türkiye'nin Deniz Alanlarındaki Sınır Anlaşmaları ve Güncel Durum”, Uluslararası Deniz Hukuku'nda Kıyı Devletinin Gemilere El Koyma Yetkisinin Sınırları Sempozyumu, Ersan Başar (Ed.), Karadeniz Teknik Üniversitesi Trabzon, ORSAM Kitapları No: 2, Ankara, Mart 2011, s. 9.

${ }^{28}$ Bülent Okan Güngören, "Türkiye'nin Deniz Yetki Alanları Üzerine Bir İnceleme”, Dokuz Eylül Üniversitesi (Yayınlanmamış Tez), 2006, ss. 55-58.

${ }^{29}$ Nuray Karapınar, ss. 13-21.

${ }^{30}$ Arda ÖZKAN, "Kıta Sahanlığının Sınırlandırılmasında Uluslararası Uygulamalar: Sözleşmeler, İçtihat Ve Doktrin", The Journal of Academic Social Science Studies, 
şeklinde tanımlanmıştır.

Kıta sahanlığı bölgesinin kapsamı incelendiğinde kenar devlet bu deniz bölgesinde doğal kaynakların aranması ve işlenmesi konusunda sınırlı yetkilere sahip olduğu anlaşılmaktadır. Güvenlik, ulaşım ve canlı kaynaklardan yararlanmada ise açık deniz statüsündeki hususlar geçerlidir. ${ }^{31}$

BMDHS'ne göre,

"Kıyı devletine kara sularının başlandığı hattan itibaren 200 mil genişlikteki deniz alanında kalan su katmanı ile deniz yatağı ve onun toprak altında ekonomik haklar ve yetkiler tanıyan denizalanı münhasır ekonomik bölge (MEB)" olarak tanımlanmıştır. Aynı sözleşmeye göre "MEB özel hukuki rejime tabidir. Kenar devletinin hak ve yetkileri ile diğer devletlerin hakları ve serbestlikleri BMDHS'nin ilgili maddeleriyle düzenlenmiş ve Münhasır Ekonomik Bölge, BMDHS'nin 55'ten 60'a kadar olan maddelerinde açıklanmıştır. Münhasır Ekonomik Bölge kavramı daha çok ekonomik ve hukuksal bir anlama sahiptir. Kita sahanlığı kavramı ile karşılaştırıldığında MEB kavramının daha geniş̧ bir uygulama alanı vardır. Bu nedenle uluslararası alan ve güvenlik anlamında ülkeler genelde kıta sahanlığ MEB kavramının üzerine yoğunlaşmaktadır., ${ }^{23}$

2015, Number: 31 Winter II, s. 367-386.

${ }^{31} \mathrm{https}$ ://www.kdhukuk.com/kita-sahanligi/ (Erişim Tarihi: 16.05.2020)

${ }^{32}$ Nuray KARAPINAR, a.g.e., ss. 13-21.

533

Güvenlik Stratejileri

Cilt: 16

Say1: 35 


\section{4}

Güvenlik

Stratejileri

Cilt: 16

Sayı: 35

\section{Şekil-1: BMDHS (Birleşmiş Milletler Deniz Hukuku Sözleşmesi)'ne göre Deniz Alanlari ${ }^{33}$}

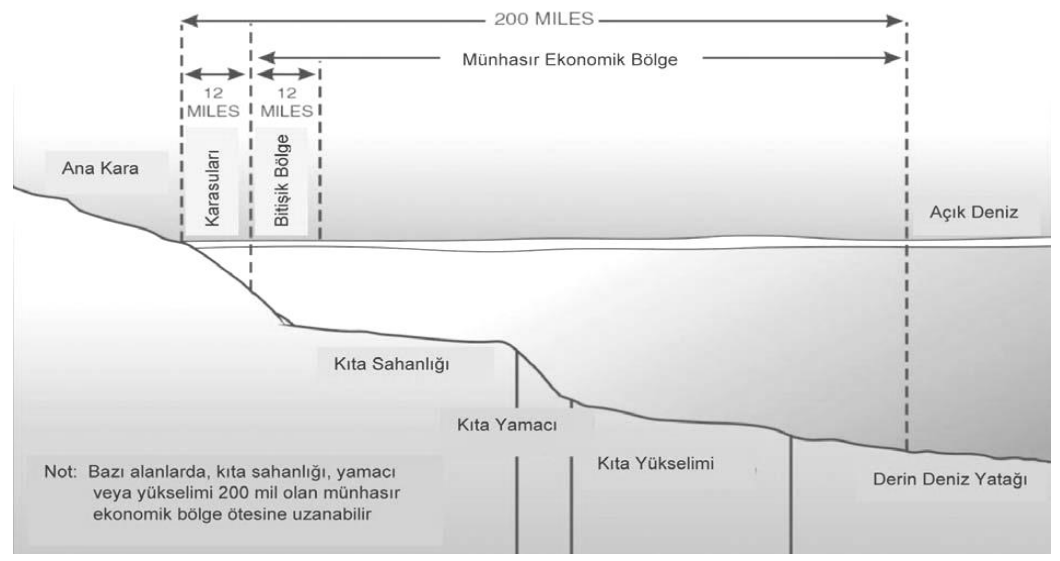

Münhasır ekonomik bölge ve kıta sahanlığı arasındaki farklar ise; Kıta sahanlığının doğal oluşum, münhasır ekonomik bölgenin ise suni olduğu, kıta sahanlığının istisna durumlarda 350 mile kadar çıkabileceği, münhasır ekonomik bölgenin ise mutlak şekilde 200 mil olacağı belirtilmiştir. Münhasır ekonomik bölgenin kıta sahanlığından ayıran su kütlesindeki kaynaklara da sahip olma hakkını içermesi, ancak münhasır ekonomik bölgede ise balıkçılık, bilimsel araştırma yapma ve suni ada yetkisinin kıyı devletine ait olmasıdır. ${ }^{34}$

Bu kavramsal çerçevede Somali’nin deniz sınırlarının belirlenmesine yönelik olmak üzere, 10 Eylül 1972'de Somali Parlamentosu, 37 sayılı Kara Denizleri ve Limanlar Kanunu'nu kabul etmiştir. Böylece, Somali

\footnotetext{
${ }^{33}$ http://www.mta.gov.tr/v3.0/sayfalar/hizmetler/kutuphane/ekonomi-bultenleri/2015_20/3.pdf (Erişim Tarihi: 23.04.2020)

${ }^{34}$ Ümmühan Elçin Ertuğrul, "Birleşmiş Milletler Deniz Hukuku Sözleşmesine Göre Kıyı Devletinin Egemen Hakları”, Gazi Üniversitesi Hukuk Fakültesi Dergisi, 2017, C. XXI, Sa. 1, s. 55.
} 
karasularını kıtasal ve ada sahillerinde 200 deniz miline çıkarmış ve 26 Ocak 1989'da Parlamento, Somali Denizcilik Kanununu kabul ederek karasularını ve münhasır ekonomik bölgesini belirlemiştir. 9 Şubat 1989'da ise Somali parlamentosu, Birleşmiş Milletler Deniz Hukuku Sözleşmesini (United Nations Convention of the Law of the Sea-UNCLOS)) onaylamıştır. Anlaşma ile ulusların dünya okyanuslarını kullanma haklarını ve sorumluluklarını tanımış ve aynı zamanda işletmeler, çevre ve deniz doğal kaynaklarının kullanımı anlamında k1lavuzlar oluşturulmuştur. 1982 UNCLOS Somali'ye 350 millik bir kıta sahanlığı ve MEB sağlamıştır. ${ }^{35}$

İç savaş sonrası Somali geçici parlamentosu, Somali hükümeti ile Kenya arasında oluşturulan mutabakat zaptına tepki gösteren kamuoyunu dikkate alarak 25 Ekim 2011 tarihinde bu konuda dördüncü yasayı (Dhahal-Dhawr) kabul etti. Ayrica Somali'nin denizlerini yönetmesini sağlayan 1989 Deniz Yasasını destekleyen başka bir yasayı da onayladı. Parlamento, konuyu Somali'nin etkili bir şekilde müzakere etme kapasitesine sahip olana kadar Somali'nin denizcilik kaynakları ile ilgili hükümet faaliyetlerine moratoryum uygulayarak mutabakat zaptını geçersiz kıldı. Sonunda, parlamento yasayı ihlal eden herkesin hain kabul edileceğini ilan etti. ${ }^{36}$

Birçok Somalili, özellikle yasa koyucular, Kenya ve bazı Batılı petrol şirketlerinin Somali'nin kaynaklarını sömürdüğüne ve zayıf bir Somali devletinden faydalandığına inanmaktadır. Somalili gazeteciler, politikacılar ve aydınlar Somali kamuoyunu harekete geçirerek Somali'nin topraklarının ve kaynaklarının bir kısmını Kenya'ya kaybettiğine dair yaygın bir düşünceye sahipler. Bunun Somali hükümeti için korsanlıkla mücadele mevzuatı veya denizle ilgili başka bir yasa geliştirmede ciddi etkisi olmuştur.

\footnotetext{
35 "UNCLOS Convention Overview", https://www.un.org/depts/los/convention agreements/convention_over view_convention.htm (Erişim Tarihi: 23.04.2020)

${ }^{36}$ Afyare Elmi, Ladan Affi, Barriers to Developing Anti-Piracy Law in Somalia", Al Jazeera Centre for Studies, 20.11.2014, https://studies.aljazeera.net/en/reports/2014/11/2014112010310522448.html.
}

535

Güvenlik Stratejileri

Cilt: 16

Say1: 35 


\section{Cem OĞULTÜRK}

\section{6}

Güvenlik Stratejileri

Cilt: 16

Sayı: 35

Başarısız devlet (failed state) tanımına tam olarak uygun nitelendirilen Somali, iç savaş nedeniyle devlet kurumlarının hafızasını yitirmiş, Kenya ile olan deniz sınırını bağımsız olarak sınırlama ve Kenya ile eşit pozisyonda müzakere etme kapasitesi de kaybolmuştur. Somali yetkilileri karmaşık denizcilik konularını anlama ve idare etme konusunda zayıf kalmışlar ve bu konuda politika oluşturmak konusunda net bir tutum sergileyememişlerdir.

Somali kıyılarındaki korsanlığın yükselmesi nedeniyle, denizcilik sorunları çeşitli hükümetler ve uluslararası ajanslar için bir öncelik haline gelmiștir. Birleșmiş Milletler Genel Sekreteri'nin Somali Özel Temsilcisi (Special Representative of the Secretary General-SRSG) Ahmedou Ould Abadallah, Ekim 2008'de Somali'ye BM Genel Sekreterine sunulmak üzere kıta sahanlığının sınırlandırılması konusunda yardımcı olmaya başladı. Somali Özel Temsilcisi’nin ofisi ayrıca Somali hükümetini, kıta sahanlığının sınırlandırılması konusunda Norveç hükümetinin ve Norveç Petrol Müdürlüğünün yardımını kabul etmeye ikna etti. Bunu takiben, Kenya ve Somali, aralarındaki deniz anlaşmazlığını çözmek için 7 Nisan 2009 tarihinde Mutabakat Zaptı imzaladı. Birleşmiş Milletler Genel Sekreteri'nin Somali Özel Temsilcisi'nin yardımıyla Somali Geçiş Hükümeti Nisan 2009'da Kıta Sahanlığı Sınırları Komisyonu'na ön bilgi ile birlikte Mutabakat Zaptı'nın tam metnini sundu. Birleşmiş Milletler Genel Sekreteri’nin Somali Özel Temsilcisi Ould Abdallah ve Somali kabinesi Mutabakat Zaptı'nı Kenya ile deniz sınırını çizecek bir ön adım olarak görmekteydiler. Ancak, Somali medyası Mutabakat Zaptı'nın Kenya ile imzalanmasını kamuoyuna ihanet olarak lanse etti ve Somali hükümetinin ülkenin çıkarlarını sattığını savundu. Somalili politikacılar ise çelişkili tutum içerisine girdiler. Eski Başbakan Omar Abdirashid Ali Sharmarke, biri Kenya ile mutabakat zaptını savunan diğeri ise Somali parlamentosunun anlaşmayı reddetmesini destekleyen iki çelişkili doküman sundu. İlk olarak Sharmarke, Kenya tarafindan Kita Sahanlığı Sinırları Komisyonu'na (Commission on the Limits of the Continental ShelfCLCS) gönderilen haritalarda belirtilen denizcilik bölgesi iddialarına itiraz etmesine rağmen, Somali ve Kenya'nın dış kıta sahanlığının sinırlandırılması konusunda CLCS'nin tavsiyelerde bulunmaya devam 
etmesini kabul etti. Ancak Başbakan Sharmarke iki ay içerisinde tutumunu değiştirerek BM Genel Sekreterine, mutabakat zaptının Somali parlamentosu tarafindan reddedildiğini bildiren ve dava edilemez olduğunu tekrarlayan başka bir mektup daha sundu. 2012 y1lında göreve başlayan yeni hükümette de kafa karışıklığı devam etmekteydi. ${ }^{37}$

Yeni Cumhurbaşkanı seçilen Hasan Şeyh Mahmud'un Somali Sahili Korsanlığg Temas Grubu'nun toplantısında yaptığı konuşmada doğru bir şekilde Somali Deniz Yasası'nın UNCLOS III ile hiçbir muğlaklık bulunmadan uyumlu olduğunu aktarırken, Başbakan Abdi Farah Shirdon ve kabinesi ise bir basın açıklaması ile 37 sayılı Kara Denizleri ve Limanlar Kanunu'nu desteklemiş ve Somali'nin Kenya ile deniz sınırlarının sınırlandırılmasına ilişkin herhangi bir diyalog açmanın doğru zaman olmadığını söylüyordu. 4 Şubat 2014'te Somali Dışişleri Bakanı Abdirahman Beileh, Birleşmiş Milletler Genel Sekreteri Ban Ki Moon'a Kıta Sahanlığı Sınırları Komisyonu'nun (Commission on the Limits of the Continental Shelf-CLCS) Somali ve Kenya dış kıta sahanlığ hakkında herhangi bir öneri getirmemesini isteyen bir mektup yazdı. Beileh ayrıca, Mutabakat Muhtırasının "hükümsüz ve geçersiz" olarak görülmesi gerektiğinin altını çizdi ve Somali davasında mutabakat referanslarının tamamen kaldırılmasını istedi. ${ }^{38}$

Hasan Şeyh Mahmud, 30 Haziran 2014 tarihinde Somali Denizcilik Yasası ile ilgili yaptığı açıklamada "Somali Federal Cumhuriyeti için münhasır ekonomik bölge sualtında veya toprak altında olsun, doğal kaynakların araştırılması, korunması ve yönetilmesi, sulardan, akımlardan ve rüzgârdan enerji üretimi gibi bölgenin ekonomik egemenlik

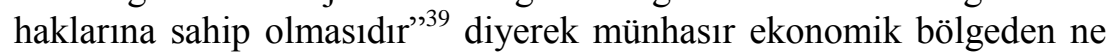
anladıklarını net şekilde ifade etmiştir.

\footnotetext{
37 A.e.

38 A.e.

${ }^{39}$ https://www.revolvy.com/main/index.php?s=Exclusive $\% 20$ economic $\% 20 \mathrm{zone} \% 20$ of\%20Somalia (Erişim Tarihi: 23.04.2020)
}

\section{7}

Güvenlik Stratejileri

Cilt: 16

Say1: 35 


\section{Cem OĞULTÜRK}

538

Güvenlik Stratejileri

Cilt: 16

Sayı: 35

Somali için münhasır ekonomik bölge kavramını önemli kılan esas nedenlerden birisi, Somali'nin Afrika'nın en uzun sahil şeridine ve kıtanın en zengin balık rezervlerine sahip olmasıdır. Bölgedeki balıkçılık açısından zenginliği, soğuk besin bakımından zengin olan yeraltı okyanusu sularının kıyıya yayılmasının bir sonucudur. Okyanusa kıyısı olması dolayısıyla fitoplankton ve zooplankton ${ }^{*}$ açısından zengin olması sebebiyle açık denizde yaşayan ekonomik değeri yüksek balıkların yaşaması için uygun ortam sağlamaktadır. ${ }^{40}$ Ayrıca bölgenin Yemen ve Kenya açıklarında olduğu gibi potansiyel petrol rezervlerine sahip olması önemini artırdığı gibi, Kenya tarafından lisans verilen petrol şirketlerinin katılımıyla Kenya ile yaşanan deniz sınır problemini daha da karmaşıklaştırmıştır.

\section{Somali - Kenya Deniz Sınırı Sorunu}

Bir kenar devleti olarak Somali özellikle uluslararası ticaret için Afrika Boynuzu'ndaki en uzun sahil şeridi ile stratejik bir öneme sahiptir. $\mathrm{Bu}$ stratejik konumunu da etkili ve caydırıcı bir kara, hava ve deniz gücü ile sağlayabilir. Özellikle sahip olduğu uzun sahil şeridi deniz gücü ve özellikle korsancılığa karşı güvenlik anlamında Sahil Güvenliğe ihtiyacını ortaya çıkartmaktadır. Özellikle birçok devletle karşılaştırıldığında (Çin, Vietnam ve Filipinler de dâhil olmak üzere Güney Çin Denizi'nde) soruna sebep olan karasuları, kıta sahanlığı ve münhasır ekonomik bölge konusunda güneyinde herhangi bir devlet olmaması aslında ülkeyi oldukça avantajlı bir konuma sokmaktadır. Uzun sahil şeridiyle paralel olarak sahip olduğu oldukça geniş kara suları, kıta sahanlığı münhasır ekonomik bölgesi ülkeye bu bölgede oldukça geniş bir alanda hâkimiyet sağlamaktadır.

Bağımsızlığından bu yana hem iç hem de dış siyaseti çatışma ve iç savaşlarla geçen Somali, kendi içinde yaşadığ 1 sorunlar nedeniyle, komşu ülkeler etkilerini Somali üzerinde artırmışlar ve ülkenin zayıflığı üzerinden kapasiteleri doğrultusunda çıkar sağlamaya çalışmışlardır.

\footnotetext{
" Bitkisel planktonlara "fitoplankton", hayvansal olanlarına ise "zooplankton" adı verilir.

${ }^{40} \mathrm{http} / / /$ securefisheries.org/sites/default/files/SecuringSomaliFisheries-FullReport.pdf (Erişim Tarihi: 23.04.2020)
} 
Son dönemde Somali, devletin yeniden inşası sürecinin yavaş da olsa başarılı yürümesi ve El-Şebab terör örgütünün etkisinin azalmaya başlaması ile toparlanma sürecine girmiştir. Özellikle yaklaşık 3000 kilometre sahil şeridine sahip ülkenin balıç̧ılık ve petrol-gaz potansiyelini kullanarak çöken ekonomisini düzeltme yoluna girmiştir. ${ }^{41}$ Ülke iç sorunlarını çözdükçe uluslararası alanda göz önünde bulundurulmayan yasal haklarını aramaya ve egemenliğini korumaya yönelik çalışmalar yapmaya başlamıştır. ${ }^{42}$

Etiyopya ile Ogedan, Kenya ile Kuzey Doğu Bölgesi'ndeki etnik Somalilerin durumu ve Kenya ile deniz sınırı sorununa çözüm arama çalışmaları bunların en önemlilerinden bir kaçıdır. Afrika'nın Hint Okyanusunda bulunan kıyısındaki 100.000 kilometrekarelik dar üçgen şeklindeki alan Kenya ve Somali arasındaki deniz sınırı anlaşmazlığının temelini oluşturmaktadır. İki ülke de söz konusu bölgenin zengin petrol ve gaz kaynaklarına sahip olması sebebiyle hak iddia etmektedir. ${ }^{43}$

Kenya, deniz sınırlarının enlem çizgilerine paralel olacak şekilde görüşlerini oluşturmakta ve bu durum Kenya'ya oldukça geniş bir alan sağlamaktadır. Bu kapsamda, Kenya yapmış olduğu anlaşmalarla bu sınırlara göre bazı uluslararası şirketlere petrol çıkarma ruhsatını vermiştir. Fakat Somali deniz sınırlarının bu şekilde belirlenmesini kabul etmemektedir. Somali, iki ülke arasındaki deniz sınırının eşitlikçi bir çizgi (equidistant line) olması gerektiğini ve Kenya'nın tartı̧malı bölgedeki petrol arama faaliyetlerinin yasa dışı olduğunu iddia etmektedir. Somali, deniz sınırının güneydoğu kara sınırının bir uzantısı olarak uzanması gerektiğini iddia etmektedir. (Harita 2)

\footnotetext{
${ }^{41} \mathrm{http}$ ///allthingssomali.com/somalia-sues-kenya-at-the-international-court-of-justice/ (Erişim Tarihi: 25.04.2020)

${ }^{42}$ Türkiye için anlam ve önemi bkz. Sedat Aybar, Değişen Afrika, Yeni Paylaşım Savaş1 ve Türkiye'nin Stratejisi,7 Ocak 2020 https://www.dunyabulteni.net/afrika/ degisen-afrika-yeni-paylasim-savasi-ve-turkiyenin-stratejisi-h457154.html (Erişim Tarihi: 17.08.2020)

${ }^{43}$ www.dw.com/en/kenya-or-somalia-who-owns-the-sea-and-what-lies-beneath/a19557277 (Erişim Tarihi: 25.04.2020)
}

\section{9}

Güvenlik Stratejileri

Cilt: 16

Say1: 35 


\section{0}

Güvenlik Stratejileri

Cilt: 16

Sayı: 35

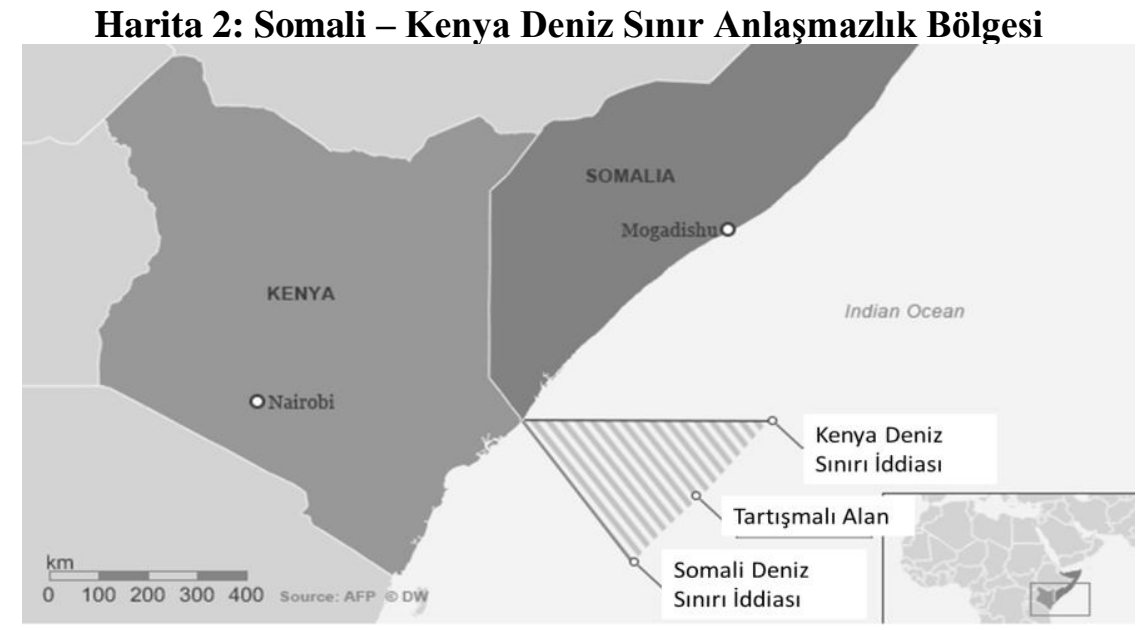

Konunun tarihi sürecine bakacak olursak Kenya, Somali ile deniz sınırını dört kez değiştirmiştir. İlk olarak, UNCLOS'un 15. Maddesinde belirtilen eşitlik ilkesini izleyen 1972 tarihli Bölgesel Sular Yasası ile bir sınır oluşturulmuştur. ${ }^{44}$ İkincisi, 28 Şubat 1979 'da Kenya Cumhurbaşkanı'nın, 1 derece 38'inci enlem ölçüsünü takiben sınırı 19'a çeviren bir Kenya Başkanlık Bildirisi yayınladığında gerçekleşmiştir. ${ }^{45}$ Kenya, deniz sınırını 1972 Bölgesel Sular Yasası'nın belirlediği 1989 tarihli Denizcilik Bölgeleri Kanunu ile 1989'da üçüncü kez tekrar belirlemiştir. $^{46} 17$ yıl sonra Kenya, 9 Haziran 2005 'te yayınlanan ve hâlen devam eden davada itiraz edilen sınır çizgisini kuran Kenya Başkanlık Bildirgesi’nde dördüncü kez sınırı değiştirmiştir. ${ }^{47}$ Buna ek

44 Territorial Waters Act 1972 (Act No. 2 of 1972) http://extwprlegs1.fao.org/ docs/pdf/ken3571.pdf (Erişim Tarihi: 17.08.2020)

${ }^{45}$ Proclamation by the President of the Republic of Kenya of 28 February 1979, http://extwprlegs1.fao.org/docs/pdf/ken4655.pdf (Erişim Tarihi: 17.08.2020)

46 Maritime Zones Act, 1989 (Cap. 371). http://extwprlegs1.fao.org/docs/ pdf/ken3534.pdf (Erişim Tarihi: 17.08.2020)

${ }^{47}$ Presidential Proclamation of 9 June 2005, pursuant to article 16, paragraph 2, and 
olarak, 1988 yılında Kenya ile deniz sınırı sınırlarını belirleyen Somali Denizcilik Yasası, Kenya'nın ihtilaflı deniz bölgesi üzerinde yaptığı tarihî iddialarla doğrudan çelişmektedir. Bu nedenle, Kenya'nın söz konusu bölgedeki tarihî iddiası, Somali'nin iddiasından daha meşru değildir. Kenya'nın söz konusu deniz bölgesine olan tarihî iddialarının tutarsızlığı, Kenya'nın bu toprak üzerinde tarihten gelen bir hakk1 olduğu iddiasını geçersiz kılmaktadır. ${ }^{48}$

1979 tarihli Kenya Başkanlık Bildirgesinde ilk talep edildiği gibi enlemin paralelinde olmasıdır. Bu deniz sınırı, 2005'teki İkinci Başkanlık Bildirgesi'nde daha fazla doğruluk için revize edilmiştir. 2009 yılında, Birleşmiş Milletler Kıta Sahanlığı Sınırları Komisyonuna sunulduğunda Kenya, 200 deniz mili ötesinde iddiasını kıta sahanlığının dış sınırlarına uzatmıştır. $^{49}$

2009 yilında, her iki ülke de Birleşmiş Milletler'in sınır anlaşmazlıklarına aracılık etmekten sorumlu Kıta Sahanlığı Sınırları Komisyonun sınır çizgisini bir kez ve bundan sonraki zamanlar için sınırsız olarak belirlemesi gerektiğgi konusunda anlaştılar. Ayrıca, konunun mahkemeye gitmesini gerektirmeyecek bir çözüm bulmak için birlikte çalışmaya devam etmeleri konusunda anlaştılar. Fakat Somali perspektifinden durum istenilen şekilde çözülemeyince anlaşmazlık yeni bir boyuta geçti. Somali, 35 yılı aşkın bir süren başarısız devlet süreci içerisinde, iki ülke arasındaki enlem sınırı boyunca deniz sınırını kabul etmiş ve herhangi bir itirazda bulunmamıştır. Somali'de devlet kurumlarının ve ülke içi birliğin giderek güç kazanması ile Somali, Kenya'nın dayattığı hususlara karşı yasal haklarını koruma yolunu seçmiştir.

article 75, paragraph 2, of UNCLOS (L.N. No. 82 of 2005). http://extwprlegs1.fao.org/ docs/pdf/ken158811.pdf (Erişim Tarihi: 17.08.2020)

48 "Maritime Delimitation in the Indian Ocean (Somalia v. Kenya) Report", United Nations International Court of Justice, ARGUED: 19 November 2017 DECIDED: 19 November 2017.

${ }^{49} \mathrm{http}: / / \mathrm{www}$. theeastafrican.co.ke/news/Somalia-allowed-Kenya-border-case/25584302426-107tp64/index.html (Erişim Tarihi: 27.04.2020) 


\section{Cem OĞULTÜRK}

542

Güvenlik Stratejileri

Cilt: 16

Sayı: 35

Somali'nin, Kenya ile mutabakat zaptını imzalamayı reddetmesiyle, BM onayı devreden çıtı ve 12 Mart 2010 tarihinde belge "eyleme geçilmez" olarak nitelendirildi. Bu sebeple 2014 yılında Somali, Kenya'ya Lahey'deki Uluslararası Adalet Divanı'nda (ICJ) dava açma yoluna gitti. Mahkemeye gitme kararı, ikili veya bölgesel girişimlerin başarısız olması durumunda, deniz alanlarındaki sınır anlaşmazlıklarını çözmenin tek yolu olarak gözükmüştür. ${ }^{50}$

Mahkeme, bugünkü durumda Somali lehine karar verilmesini sağlayan, eşitlik ilkesinin uygulanmasına karar vermiştir. "Eşitlik İlkesi", her bir devletin kıyı şeridinden orantılı olarak uzak olan enlem ve boylam noktalarından oluşan mevcut arazi sınırından denize doğru düz bir çizgi olarak tanımlanabilir. Fakat Birleşmiş Milletler Deniz Hukuku Konvansiyonu'nun 15 numaralı kararında bazı istisnaların olabileceği belirtilmiştir. Bu maddeye göre; iki devletin karasularını sınırlamak için tarihî gelişmeler veya diğer özel şartlar nedeniyle sağlam temellere dayanarak iki ülke anlaşmış olduğu durumlarda "Eşitlik İlkesi" geçerli olmayabilir. $\mathrm{Bu}$ madde sadece karasularını ifade etse de mahkeme tarafından münhasır ekonomik bölge ve kıta sahanlığı içinde geniş manada kapsamına alabileceği ifade edilmiştir. Ancak maddede belirtildiği üzere tarihî gelişmelere bakıldığında Kenya ve Somali arasında karşılıklı bir tarihî anlaşma yapılması zor görünmektedir. Buna gerekçe olarak sınırın orantısız bir şekilde Kenya lehine oluşu ve Kenya'nın bu sınırı kendi başına belirlemesi Somali'nin politikasını şekillendirmiştir. Mahkemenin, Kenya'nın iddiası dâhilinde, tarihî bir geçmişten ötürü eşitlik ilkesinin geçerli olmadığını söylemesi mümkün görülmemektedir. Sınır, 15'inci maddede yer alan koşullar dahilinde tarihsel bir argüman olarak kabul etmek için geçerli olmadığından; Kenya, Deniz Hukuku Konvansiyonu'nu ihlal etmektedir. Ayrica karasuları konusunda devletin güvenliği, ticaretin düzenlenmesi gibi egemenlik haklarını koruyabilmesi adına zaten karasularının 12 mil

${ }^{50} \mathrm{http} / / / \mathrm{www}$. statelaw.go.ke/press-statement-on-the-status-of-kenya-somalia-maritime -boundary-dispute-at-the-international-court-of-justice-in-the-hague-the-netherlands/ (Erişim Tarihi: 27.04.2020) 
güneye doğru sınır hattı çizgisine göre uzanması şartı bulunmaktadır.

UAD, Deniz Hukuku Konvansiyonu'nun 15. maddesi gereği mahkemenin ihtilaflı taraflar arasında arabuluculuk yapabileceğini, Kenya'nın mahkemeyi erteleme konusundaki istekliliğini kabul ettiğini ve bu nedenle Somali'nin egemenliğini kısıtlamak için açık bir girişimde bulunmadığını tespit etmiştir.

Mahkemeye göre tartışmalı alanda meydana gelen ekonomik faaliyetler haklı bir şekilde Somali'ye ait olmalıdır. Ancak, Kenya'nın bu süreçte iyi niyet gösterdiği, Somali'nin de Kenya'nın bölgede yapmış olduğu yatırımlara yönelik giderlerini Kenya'ya geri ödeyen bir ödeme planı oluşturmak için görüşmesi önerilmektedir. Ne olursa olsun Somali, tartışmalı MEB ve kara denizinde yegâne bir iddiaya sahiptir, öngördüğü her şekilde hareket edebilir ve Kenya'nın tartışmalı bölgeye karşı yasal bir hakkı bulunmamaktadır. Bununla birlikte, sınırda yeni bir düzenlemenden doğacak olumsuz durumları ele almak için, mahkeme Somali ve Kenya'y1, her iki tarafın da lehine olacak şekilde, deniz alanlarının potansiyel takaslarını müzakere etmeye teşvik etmiştir. Böyle bir iş birliği olduğu takdirde mahkeme tarafından onaylanacağı belirtilmiştir.

Somali, Uluslararası Adalet Divanı'nın Birleşmiş Milletler Deniz Hukuku Sözleşmesi ve diğer uluslararası deniz kanunları tarafından belirlenen sınırın kesin bir şekilde tanımlamasını istemektedir. Mahkemeye göre tartışmalı durumlarda, eğer herhangi bir doğal engel yoksa her iki kıyı şeridine aynı mesafede olan bir hat boyunca geçici bir sınır çizilir. Daha sonra, bu sınırın her iki taraf için adil olup olmadığını ya da biri ya da diğeri yararları ya da dezavantajları olup olmadığını görmek için bir sınama dönemi uygulanır. Ancak Kenya hükümeti, daha önce anlaşılan sınır çizgilerine sadık kalmaktadır ve yaklaşık 100 yıl boyunca bu çizginin sınır olduğunu düşünerek hareket etmiştir. Buna göre de yatırımlarını planlamış ve uzun vadeli petrol şirketleri ile anlaşmalar yapmışıı. ${ }^{51}$

\footnotetext{
51 https://www.dur.ac.uk/ibru/news/boundary_news/?itemno=28173\&rehref=\%2Fibru
} 
544

Güvenlik

Stratejileri

Cilt: 16

Sayı: 35

Harita 3: Kenya'da Petrol ve Gaz Arama Firsatları ${ }^{52}$

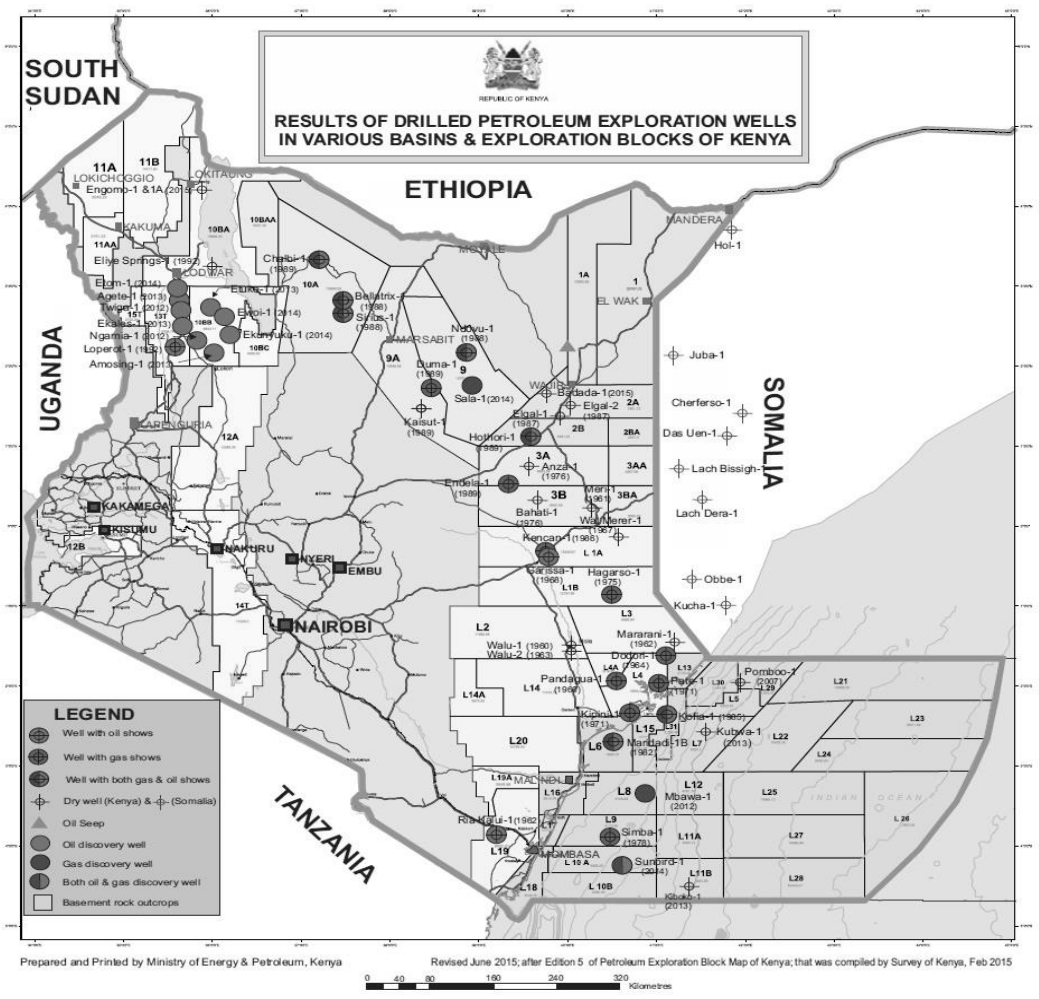

Eğer bu karar uygulanırsa Kenya petrol araması yaptığı haritada gözüken potansiyel hidrokarbon yatakları olan L5 ve L22 bloklarından önemli bir kısmı kaybedecektir. ${ }^{53}$ Bu durum bölgedeki uluslararası enerji şirketlerini oldukça etkileyecektir. 2012 yılında Kenya, şirketlere

$\% 2$ Fnews $\% 2 F \&$ resubj=Boundary + news + Headlines (Erişim Tarihi: 27.04 .2020 )

${ }^{52} \mathrm{https}$ ///nationaloil.co.ke/opportunities-for-oil-exploration/

${ }^{53} \mathrm{https} / / / \mathrm{www}$.theeastafrican.co.ke/tea/news/east-africa/un-top-court-sets-date-forcase-on-kenya-somalia-border-dispute-1350436 (Erişim Tarihi: 27.04.2020) 
satış için tartışmalı olan bölgede L-5, L-21, L-22, L-23, L-24 ve L-25 bloklarının da dâhil olduğu sekiz yeni off-shore blok açmıştır. ${ }^{54} 2010$ y1lında Amerikan şirketi Anadarko Petroleum Şirketine L-5 Blokunu vermiştir (Daha sonraki raporlar Anadarko'nun 2012'nin sonlarında veya 2013 başında ilgisinden vazgeçtiğini gösteriyor). L-5, L-21, L-22, L-23 ve L-24, L-25, L-26 ve L-27 bloklarının yine önemli bir kısmı ise eşitlik çizgisinin Somali tarafında yer almaktadır. 2012 yılında İtalyan firması Eni S.p.A'ya, L-22 bloğu ise Fransız şirketi Total S.A'ya verilmiştir. Basında çıkan haberlere göre, 2012 yılında, Total S.A Şirketi'nin Kenya yönetimiyle L-22'yi yüzde 100 oranla işletmek üzere bir üretim paylaşım sözleşmesi yaptığını ve Anadarko tarafından işletilen L-5'in yüzde 40'lık oranına sahip olduğunu doğrulamıştır. Bundan istifade ederek Somali'de enerji şirketlerini tartışmalı bölgeyi araştırmak üzere sözleşme yapmaya davet etmiştir. ${ }^{55}$ Eğer UAD Somali'nin sınır konumunu olması gerektiği gibi belirlerse, Shell ve Dominion Energy'ye ait olan 10, 11 ve 12 numaralı blokların Tanzanya'nın kontrolünde olmasi durumunun da sorgulanmas1 sonucunu ortaya çıkaracaktır. ${ }^{56}$ Çünkü şu anda Kenya'nın güneyde Tanzanya ile olan deniz sınırı da aynı Somali ile olduğu gibi kara sınırına göre değil enlemlere paralel olarak belirlenmiştir.

Sorunun geldiği nokta itibari ile Kenya, Somali makamlarının ise kararın çıkmasını beklemeden ihtilaflı sularda petrol ve doğal gaz arama ihaleleri düzenlemesi nedeniyle Somali ile diplomatik ilişkilerini kesmiş, Somali ise attığı adımların yeniden müzakere masasına oturma amaçlı olduğunu açıklamıştır. Kenya'nın UAD'nin vereceği kararın kendi aleyhine çıkma ihtimalinin yüksek olması gerginliğin artırmasına yol açmıştır.

\footnotetext{
54 "Somalia Takes Kenya to U.N. Court in Oil Rights Row", Reuters, Aug. 29, 2014, http://www.reuters.com/article/us-world-court-somalia-kenyaidUSKBNOGTOFW201408298 (Erişim Tarihi: 27.04.2020)

55 "Somalia Invites Energy Companies to Explore for Oil", BBC, Dec. 8, 2014, http://www.bbc.com/news/ business-29993447 (Erişim Tarihi: 27.04.2020)

${ }^{56}$ https://www.reuters.com/article/us-kenya-exploration/kenya-somalia-border-rowthreatens-oil-exploration-idUSBRE83J0M120120420 (Erişim Tarihi: 27.04.2020)
}

\section{5}

Güvenlik Stratejileri

Cilt: 16

Say1: 35 


\section{Cem OĞULTÜRK}

546

Güvenlik Stratejileri

Cilt: 16

Sayı: 35

UAD'nin Somali-Kenya deniz sınırı hakkında nihai kararı, şüphesiz Doğu Afrika'nın açık deniz kalkınmasının geleceğini etkileyecektir. Denizaşırı kalkınma için Kenya ve Tanzanya ile sözleşme yapan ve Somali ile bu tür sözleşmeleri düşünen şirketler, UAD'nin anlaşmazlığı ele alış şeklini göz önünde bulundurmaya devam etmektedir. Durum ne olursa olsun, Afrika devletlerinin deniz anlaşmazlıklarını nasıl karşılıklı ve barışçıl bir şekilde çözebileceğine dair önemli bir örnektir. Hâlihazırda Gana ve Fildişi Sahili, Atlantik Okyanusu boyunca bir sınır boğazında faaliyet gösterirken, Tanzanya'nın Malavi Gölü üzerinde bir anlaşmazlığ bulunmaktadır. Uzun vadede bu dava, daha zengin, güvenli ve iş birliğine dayalı Afrika denizcilik ülkelerine doğru hareket etme sürecinin bir parçası olması muhtemeldir.

\section{Sonuç}

Kenya'da yaşayan Somali kökenliler ile iç savaş ve kuraklığın taşıdığı mültecilerin Kenya üzerinde yaratmış olduğu olumsuz güvenlik algısı iki ülke ilişkilerini derinden etkilemiştir. Kenya'da Somali'nin yayılmacı bir yaklaşımı benimsediğine dair yaygın inanış, gerçekleşen terör saldırıları yüzünden daha da güçlenmiş, Somalililere bakışı olumsuz yönde değiştirmiştir. Etiyopya'dan da etkilenerek Somali'ye yönelik politikasını daha müdahaleci hale getirmiştir. Kenya-Somali arasında baş gösteren deniz sınırı sorunu ise kara sınırında yaşanan sorunların uzantısı olarak işin içine ekonomik boyutu da eklemiştir. Bu kapsamda sorunun çözümünde her iki tarafın iş birliğini artırıcı ve kazan-kazan stratejisi ile yaklaşımlarının barış̧̧ıl ve mevcut krizi kötüleştirecek adımlardan kaçınan tarzda olması hem bölgesel hem de küresel güvenlik açısından önem arz etmektedir.

Sorunun çözümü için her iki ülke de UAD'den davanın duruşmasını hızlandırmasını ve mümkün olan en kısa sürede nihai bir karar vermesini talep etmeli ve karara saygılı olacağını açıkça ortaya koymalıdır. Bunun kısa sürede mümkün olmaması durumunda, UAD'nin tavsiyeleri doğrultusunda Afrika Birliği ve IGAD'ın arabuluculuğunun sorunun çözümünde etkili olabileceği göz önünde bulundurulmalıdır. Zira iki ülkenin birbirlerine düşmanca yaklaşımı 
bölgede yaşanan sorunların katlanarak artmasına yol açacaktır. Sorunun barışçıl yollarla çözülmesi ise benzer sorunlara sahip diğer Afrika ülkeleri için cesaretlendirici olması açısından önem arz etmektedir.

\section{Summary}

Somalia's relations with its western neighbour Kenya is considered more positive from the past to the present compared to Ethiopia. The people of Kenya, consisting of several different ethnic groups, have existed for a long time as a colony similar to Somalis and gained independence in the early 1960s, and their boundaries have been drawn with a dictator similar to other African nations. Post-colonial Kenya has had a much more stable structure than Somalia, although it has sometimes faced domestic problems.

In this study, in addition to the land border problems between Kenya and Somalia, the approach is to look closely to the problems at maritime borders and the key reason for this is that Somali people of origin and Somali refugees in Kenya have a negative effect on the safety perception of Kenya. When studying at the problem from a security perspective, negative effect of Somalia's expansionist policy on the North East region on Kenya-Somalia relations should not be ignored.

The hypothesis of this study was that Kenya identified Somalis living in the country as a security issue in the conflict between Somalia and Kenya regarding the maritime border. The question of how to settle the Somali-Kenya maritime border dispute, which is also on the agenda of the International Court of Justice, is an excellent example of territorial waters, continental shelf and exclusive economic zone disputes in Africa and other parts of the world.

Since the independence of the conterminous states Kenya, Ethiopia and Somalia, problems have arisen among them. Ethiopia has intervened in Somalia's problems through its support to the opposition or by forming groups against the state. Kenya, on the other hand, was not very active in Somalia compared to Ethiopia, but from time to time it acted with Ethiopia, considering the expansionist policy of Somalia and 


\section{Cem OĞULTÜRK}

\section{8}

Güvenlik Stratejileri

Cilt: 16

Sayı: 35

it idea to unite the Somalis in the region in order to protect its interests.

With the collapse of the Siad Barré dictatorship in 1991, Kenya's policy towards Somalia began to resemble Ethiopia's attitude. Kenya, which has had the same problem with Ethiopia, followed a different strategy by allowing the asylum of thousands of Somalis who came to its borders with the collapse of the regime in Somalia, and as a result, it faced many security problems. After 1991, Kenya has led to a more active policy against Somalia.

After the September 11 attacks, the global struggle against the radical predecessor terrorist organizations gained importance, and the danger of spreading the territorial gains of the terrorist organization AlShabab in Somalia has added suspicion to Kenya's perception of its citizens of Somali origin and refugees. For the Muslim population living in the coastal regions of Kenya, problems regarding security and justice and youth unemployment increase political tension. In the face of the threat of Salafist terrorism among Muslims living in the coastal areas, the Kenyan authorities responding violently instead of social and economic measures increases the perception of threat originating from the Somali border.

There are unresolved problems at the maritime borders as well as at the land borders of African countries. Especially after the discovery of rich hydrocarbon reserves in the area, as well as in the rest of the world through the advancement of technology, African countries have begun to claim their rights to territorial waters, continental shelves and exclusive economic zones in the international arena. Somali governments and its international community have faced many legal and security issues since 1999, including issues of piracy on the high seas, the declaration of an Exclusive Economic Zone, and the fight against illegal fishing in territorial waters.

Somali journalists, politicians and intellectuals have a widespread notion that Somalia lost some of its land and resources to Kenya and mobilize the Somali public. This mobilization has had a serious impact on the Somali government in developing anti-piracy legislation or any other law on the sea. Described in full accordance with the definition of 
a Failed State, Somalia has lost the memory of state institutions due to the civil war, lost the capacity to independently limit the maritime border with Kenya and to negotiate on an equal position with Kenya. Somali authorities have been weak in understanding and handling complex maritime issues and have not been clear in policy-making on this issue.

549

Güvenlik Stratejileri

Cilt: 16

Say1: 35

One of the main reasons that make the concept of Exclusive Economic Zone important for Somalia is that the country has the longest coastline of Africa and the richest fish reserves of the continent. The richness of fisheries in the region is a result of the spreading of cold nutrient-rich underground ocean waters to the shore. A narrow triangular area of 100,000 square kilometres on the coast of Africa in the Indian Ocean forms the basis of the maritime border dispute between Kenya and Somalia. Both countries claim their rights here because the region in question has rich oil and gas resources.

Kenya forms its views on the maritime borders parallel to the latitude lines, and this situation provides a very large area for Kenya. In this context, Kenya has granted oil exploration licenses to some international companies according to the agreements it has made. However, Somalia does not accept such determination of sea borders. Somalia claims that the maritime border between the two countries should be an equidistant line and that oil exploration activities of Kenya in the disputed region are illegal. Somalia claims that the maritime border should be drawn as an extension of the southeast land border.

In 2014, Somalia sought to sue Kenya at the International Court of Justice (ICJ) in The Hague. The decision to go to court appeared to be the only way to resolve border disputes in maritime areas if bilateral or regional initiatives failed. The court has decided to apply the principle of equality, which allows a ruling in favour of Somalia in the present situation. ICJ has determined that the court can mediate between the disputed parties under the Article 15 of the Law of the Sea Convention, but it has also accepted Kenya's willingness to postpone the court and therefore has not made a clear attempt to restrict Somalia's sovereignty.

As of the point where the problem came, Kenya broke its diplomatic relations with Somalia due to the Somali authorities' decision 


\section{Cem OĞULTÜRK}

550

Güvenlik

Stratejileri

Cilt: 16

Sayı: 35

to hold tenders for oil and natural gas exploration in disputed waters without waiting for the decision to be taken, and Somalia declared that the steps it took were aimed to sit at the negotiation table again. It is highly probable that Kenya's decision to act against the ICS's has led to an increase in tension.

In terms of both regional and global security concerns, it is essential for both sides to increase their cooperation in the solution of the problem to have a win-win strategy and to avoid steps that will escalate the current crisis. Peaceful resolution of the problem is important in terms of encouraging other African countries having similar problems.

\section{KAYNAKÇA}

Kitaplar

BROWN Micheal, "Internal Conflict: Causes and Implications", The International Dimension of Internal Conflicts, Michael E. Brown (Ed.), Cambridge, MA: MIT Press, 1996.

CEYHUN, G.Ç., ORAL, E.Z., "Türkiye'nin Deniz Alanlarındaki Sınır Anlaşmaları ve Güncel Durum", Uluslararası Deniz Hukuku'nda Kıyı Devletinin Gemilere El Koyma Yetkisinin Sınırları Sempozyumu, Ersan Başar (Ed.), Karadeniz Teknik Üniversitesi Trabzon, ORSAM Kitapları No: 2, Ankara, Mart 2011.

ÇITAK, Emre, ŞEN, Osman, Uluslararası İlişkilerde Güvenlik Teorik Değerlendirmeler, Uluslararası İlişkiler Kütüphanesi, İstanbul, 2014.

ELMİ Afyare Abdi, Somali Kimlik İslami Hareketler ve Barış, Açılımkitap, 2012.

HOSKYNS Catherina, Case Studies in African Diplomacy, Oxford University Press, 1969

PAZARCI Hüseyin, Uluslararası Hukuk Dersleri, 2. Kitap, Ankara, 3. Bası, 1993.

SPENCER John Hathaway, Ethiopia at Bay, A Personel Acount of the Haile Sellassie Years, Reference Publications, 1984.

Tezler

GÜNGÖREN Bülent Okan, Türkiye'nin Deniz Yetki Alanları Üzerine Bir İnceleme, Dokuz Eylül Üniversitesi (Yayınlanmamış Tez), 2006.

Makaleler

CAŞIN Mesut Hakk1, “Askeri ve Stratejik Açıdan Montreux'nün Dünü ve Geleceği”, Milletlerarası Hukuk ve Milletlerarası Özel Hukuk Bülteni, Milletlerarası Hukuk Ve Milletlerarası Münasebetler Araştırma Ve Uygulama Merkezi, Kültür Sanat Basımevi, Y11 37, Say1 1, 2017. 
ERTUĞRUL Ümmühan Elçin, "Birleşmiş Milletler Deniz Hukuku Sözleşmesine Göre Kıyı Devletinin Egemen Hakları", Gazi Üniversitesi Hukuk Fakültesi Dergisi C. XXI, Y. 2017, Sa. 1.

GESHEKTER, Charles L., "Anti-Colonialism and Class Formation: The Eastern Horn of Africa before 1950", The International Journal of African Historical Studies, 1985, Vol. 18, no. 1 s. 1-32.

KARAPINAR Nuray, "Birleşmiş Milletler Deniz Hukuku Sözleşmesi Ve Deniz Alanlarına İlişkin Bazı Kavramlar”, Doğal Kay. ve Eko. Bült. (2015) 20: 13-21.

Maritime Delimitation in the Indian Ocean (Somalia v. Kenya) Report, American Model United Nations International Court of Justice, ARGUED: 19 November 2017 DECIDED: 19 November 2017, 2017.

MUSAU Stephen, "Clans' and Clannism's Control Over Weak Political Institutions", The ITPCM Vol. IX no. 34 ISSN. 2239-7949 International Commentary, 2013.

ÖZKAN Arda, "Kıta Sahanlığının Sinırlandırılmasında Uluslararası Uygulamalar: Sözleşmeler, İçtihat Ve Doktrin”, The Journal of Academic Social Science Studies, Number: 31, s. 367-386, Winter II, 2015

VANDENBERG Paul, "Ethnic-Sectoral Cleavages and Economic Development: Reflections on the Second Kenya Debate", The Journal of Modern African Studies, Vol. 41, No. 3 (Sep., 2003), ss. 437-455.

WALLENSTEEN Peter ve SOLLENBERG Margereta, “Armed Conflict,1989-2000", Journal of Peace Research 38, say1.5, 2001.

WENDT Alexander, "Constructing International Politics", International Security, Cilt 20, No 1,1995.

\section{İnternet Kaynakları}

AYBAR Sedat, Değişen Afrika, Yeni Paylaşım Savaşı ve Türkiye'nin Stratejisi,7 Ocak 2020 https://www.dunyabulteni.net/afrika/degisen-afrika-yeni-paylasim-savasi-veturkiyenin-stratejisi-h457154.html (Erişim Tarihi: 17.08.2020)

AYBAR Sedat, “Kenya'da Terör Kimin İşine Yarar”, Cumhuriyet Gazetesi, 7 Ekim 2013, https://www.cumhuriyetarsivi.com/monitor/index.xhtml?cid=2 (Erişim Tarihi: 17.08.2020) Birleşmiş Milletler Deniz Hukuku Sözleşmesi, Birleşmiş Milletler Enformasyon Merkezi UNIC-Ankara, 1982. bkz. http://did.cevreorman.gov.tr/did/Files/ UNCLOS.pdf, erişim: 28 Mart 2011. Bozkurt E., 2006. Uluslararası Hukuk Bakımından Münhasır Ekonomik Bölge Kavramının Ortaya Çıkışı, Uluslararası Hukuk ve Politika Cilt 2, No: 5.

BURBIDGE Dominic, The Kenyan State's Fear of Somali Identity, 2015, http://www.accord.org.za/conflict-trends/the-kenyan-states-fear-of-somali-identity/ (Erişim Tarihi:23.04.2020)

MUSAU Zipporah, "Kenya: Can Anyone Reconcile Somali Warlords?" AllAfrica All the Time, 11 October 2002, http://allafrica.com/stories/200210100671.html (Erişim Tarihi: 23.04.2020);

NJERİ Mũturi Wa, "Kenya That was Never Kenyan: The Shifta War \& The North Eastern Kenya", https://medium.com/@ muturi/kenya-that-was-never-kenyan-the-shiftawar-the-north-eastern-kenya-e7fc3dd31865 (Erişim Tarihi: 23.04.2020) 


\section{Cem OĞULTÜRK}

\section{2}

Güvenlik

Stratejileri

Cilt: 16

Sayı: 35

OPENDA Francis, OMBATI Cyrus, "Kenya: Warlords Who Call Nairobi Home", AllAfrica - All the Time, 16 October 2004, http://allafrica.com/stories/20041018 0169.html (Erişim Tarihi: 23.04.2020)

SWAIN Ashok, "Grand Ethiopian Renaissance Dam: Catalyst for basin-wide water cooperation?", The Africa Report, 4 Ağustos 2020. https://www.theafricareport.com/ 35797/grand-ethiopian-renaissance-dam-catalyst-for-basin-wide-water-cooperation/ (Erişim Tarihi: 17.08.2020)

http://allthingssomali.com/somalia-sues-kenya-at-the-international-court-of-justice/ (Erişim Tarihi: 25.04.2020)

Arusha Agreement on Ending of Kenyan-Somali Border Hostilities.Somali-Ethiopian Agreement.Keesing's Record of World Events(formerly Keesing's Contemporary Archives),Volume13, November, 1967 Kenya, Somalia, Ethiopia, Kenyan, Somali, Ethiopian, Page 22386 https://www.kenyatalk.com/index.php?threads/today-inhistory-shifta-war-long-read.25037/(Erişim Tarihi: 23.04.2020)

From 'Shifta' War to Al Shabaab: Why Kenya is her own worst enemy, http://owaahh.com/shifta-war-to-al-shabaab/(Erişim Tarihi:23.04.2020)

Maritime Zones Act, 1989 (Cap. 371). http://extwprlegs1.fao.org/docs/pdf/ ken3534.pdf (Erişim Tarihi: 17.08.2020)

Moi Spekas at the American Defence University, http://qaranka.com/ right/scan051a.pdf (Erişim Tarihi: 23.04.2020)

Presidential Proclamation of 9 June 2005, pursuant to article 16, paragraph 2, and article 75, paragraph 2, of UNCLOS (L.N. No. 82 of 2005). http://extwprlegs1.fao.org/ docs/pdf/ken158811.pdf (Erişim Tarihi: 17.08.2020)

Proclamation by the President of the Republic of Kenya of 28 February 1979, http://extwprlegs1.fao.org/docs/pdf/ken4655.pdf (Erişim Tarihi: 17.08.2020)

Somalia Invites Energy Companies to Explore for Oil, BBC, Dec. 8, 2014, http://www.bbc.com/news/business-29993447(Erişim Tarihi: 27.04.2020)

Somalia Takes Kenya to U.N. Court in Oil Rights Row, Reuters, Aug. 29, 2014, http://www.reuters.com/article/us-world-court-somalia-kenya

idUSKBN0GT0FW201408298 (Erişim Tarihi: 27.04.2020)

Territorial Waters Act 1972 (Act No. 2 of 1972) http://extwprlegs1.fao.org/ docs/pdf/ken3571.pdf (Erişim Tarihi: 17.08.2020)

"UNCLOS Convention Overview", https://www.un.org/depts/los/convention agreements/ convention_overview_convention.htm (Erişim Tarihi:23.04.2020)

'Whose peace is it anyway? Connecting Somali and international peacemaking', http://www.cr.org/downloads/AccordInsight_WomenBuildingPeace_Somalia.pdf (Erişim Tarihi: 22.04.2020)

http://africanarguments.org/2014/05/09/wole-soyinka-we-must-respond-to-those-whofeel-they-have-a-divine-right-to-mess-up-our-lives-by-magnus-taylor/ (Erişim Tarihi: 27.04.2020)

http://allafrica.com/stories/201712190270.html (Erişim Tarihi: 25.04.2020)

https://www.dur.ac.uk/ibru/news/boundary_news/?itemno=28173\&rehref=\%2Fibru

$\% 2$ Fnews\%2F\&resubj=Boundary+news+Headlines(Erişim Tarihi: 27.04.2020) 
www.dw.com/en/kenya-or-somalia-who-owns-the-sea-and-what-lies-beneath/a19557277 (Erişim Tarihi: 25.04.2020)

https://www.kdhukuk.com/kita-sahanligi/ (Erişim Tarihi: 16.05.2020)

http://www.mta.gov.tr/v3.0/sayfalar/hizmetler/kutuphane/ekonomi-bultenleri/2015_ 20/3.pdf (Erişim Tarihi: 23.04.2020)

https://www.reuters.com/article/us-kenya-exploration/kenya-somalia-border-rowthreatens-oil-exploration-idUSBRE83J0M120120420(Erişim Tarihi:27.04.2020)

https://www.revolvy.com/main/index.php?s=Exclusive\%20economic\%20zone\%20of \%20Somalia (Erişim Tarihi: 23.04.2020)

http://securefisheries.org/sites/default/files/SecuringSomaliFisheries-FullReport.pdf (Erişim Tarihi: 23.04.2020)

http://www.statelaw.go.ke/press-statement-on-the-status-of-kenya-somalia-maritimeboundary-dispute-at-the-international-court-of-justice-in-the-hague-the-netherlands/ (Erişim Tarihi: 27.04.2020)

http://www.theeastafrican.co.ke/news/Somalia-allowed-Kenya-border-case/25584302426-107tp64/index.html (Erişim Tarihi: 27.04.2020)

https://www.theeastafrican.co.ke/tea/news/east-africa/un-top-court-sets-date-for-caseon-kenya-somalia-border-dispute-1350436 (Erişim Tarihi: 27.04.2020)

\section{3}

Güvenlik

Stratejileri

Cilt: 16

Say1: 35 